\title{
OpenDocs
}

Title: The indignity of the Welfare Reform Act.

Citation: Walker, R., Chase, E. and Lødemel, I. (2012) The indignity of the Welfare Reform Act. Poverty, Iss: 143, pp. 9-12.

Official URL: http://www.cpag.org.uk/content/indignity-welfare-reform-act

More details/abstract: At the 101st session of its conference in June this year, the International Labour Organization agreed Recommendation 202 on national social protection floors. Esoteric though it sounds, this sets standard that has the potential to require the radical upgrading of the British social security system. Robert Walker, Elaine Chase and Ivar Lødemel provide an overview of the Recommendation's context, and argue why its rightsbased approach and emphasis on dignity matter to UK anti-poverty programmes..

Version: Published version.

Terms of use: This work has been licensed by the copyright holder for distribution in electronic format via any medium for the lifetime of the OpenDocs repository for the purpose of free access without charge. This journal provides immediate open access to its content on the principle that making research freely available to the public supports a greater global exchange of knowledge.

This is a download from OpenDocs at the Institute of Development Studies

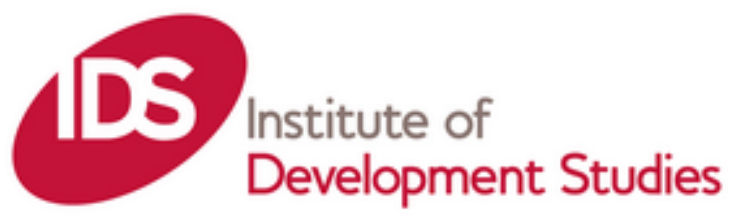




\section{The indignity of the}

\section{Welfare Reform Act}

Social security in a global context

The International Labour Organization's (ILO's) Recommendation 202 determines that all countries should provide a nationally defined minimum level of income security for its older citizens, for those of active age who are unable to earn sufficient and for children. ${ }^{1}$ In so doing, it arguably re-establishes the expectation that all countries should proactively engage in building a coherent social policy as a fundamental component of national governance, this after decades when the so-called Washington consensus promulgated the view that social policy was peripheral, redundant or even counterproductive. ${ }^{2}$

The Recommendation is the culmination of a process begun in 1952 to secure minimum social security standards ${ }^{3}$ and re-invigorated in 2006, when new efforts were made to realise this aspiration. ${ }^{4}$ The work in the early 2000 s was undertaken by civil servants in the ILO, and challenged the prevailing view that social security was too expensive an option for most countries in the global South by demonstrating that provision of a basic package of social protection was not beyond the reach of countries as poor and diverse as Nepal and Bangladesh. ${ }^{5}$

Perhaps a touch ironically, the process was given a fillip by the global crisis in 2008. In April the following year, the United Nations (UN) Chief Executive Board established the Social Protection Floor Initiative as one of its joint responses to the crisis. Under the leadership of the ILO and the World Health Organization, the Initiative brought 19 UN bodies together with the World Bank, the International Monetary Fund, regional development banks, bilateral donors, and a number of international NGOs. This network gave new legitimacy to the ILO aspirations and provided added momentum. This carried the project through from the ILO Declaration on Social Justice for a Fair Globalization, ${ }^{6}$ which called for 'social security to all, including measures to provide basic income to all in need of such protection', to the Report of the Committee for the Recurrent Discussion on Social Protection, ${ }^{7}$ the Resolution and Conclusions Concerning the Recurrent Discussion on Social Protection (Social Security) in $2011,{ }^{8}$ and then to the final vote and approval of the Recommendation in June 2012.

\begin{abstract}
At the 101st session of its conference in June this year, the International Labour Organization agreed Recommendation 202 on national social protection floors. Esoteric though it sounds, this sets a standard that has the potential to require the radical upgrading of the British social security system.
\end{abstract} Robert Walker, Elaine Chase and Ivar Lødemel provide an overview of the Recommendation's context, and argue why its rights-based approach and emphasis on dignity matter to UK anti-poverty programmes.

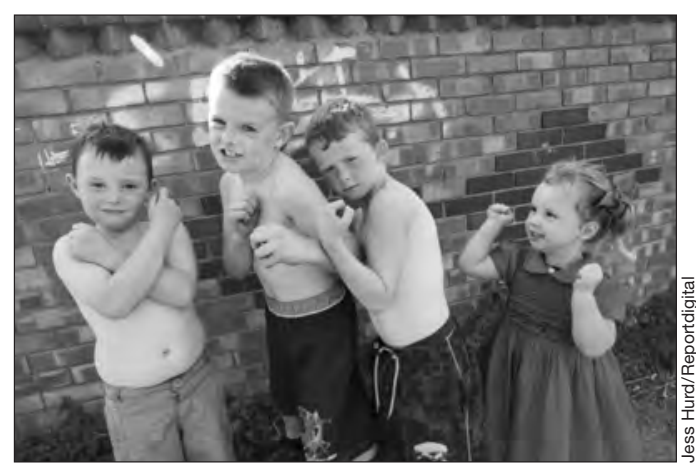

Given that the ILO is a tripartite body comprising employers' organisations, trade unions and the governments of over 180 countries, with the right of participation (though not voting powers) for select NGOs, it is hardly surprising that the final Recommendation does not include all the aspirations aired en route, but instead can be seen as a historic compromise. There is no global fund to aid the poorest countries in realising the aspirations of Recommendation 202 and no common international standard, a global social floor. Instead, states are left to determine national floors 'in accordance with national circumstances', ${ }^{9}$ albeit with the expectation that the basic income security should allow 'life in dignity'. Essentially, Recommendation 202 establishes a set of principles appertaining to the design of social security systems, based on the understanding that the right to social security is a human right. Social security provision, therefore, is not optional, something that national governments can choose not to provide or to cut out. The preamble also reminds 
national governments that social security helps overcome poverty and reduces inequality and is 'an investment in people that empowers them to adjust to changes in the economy and in the labour market'. ${ }^{10}$ Furthermore, Recommendation 202 notes that, in times of crisis, 'social security systems act as automatic social and economic stabilizers', 'help stimulate aggregate demand' and 'help support a transition to a more sustainable economy'. ${ }^{11}$ These principles apply globally and are anticipated to withstand the test of time. However, they are also a salient reminder to the British government that reductions in social security provision at this time could be counterproductive in economic terms and might also contribute to a violation of citizens' basic human rights.

\section{On the matter of dignity}

Paragraph 3 of Recommendation 202 sets out the fundamental principles that governments are now obliged to apply in the design and implementation of social protection floors. While the Recommendation was much debated and refined before the final vote, one amendment of note was the inclusion of the principle that governments should have 'respect for the rights and dignity of people covered by the social security guarantees'.

The core of the amendment can be traced to a letter sent by Magdalena Sepúlveda Carmona, the UN Special Rapporteur on extreme poverty and human rights, in April 2012. ${ }^{12}$ She had been moved to do so after attending a workshop in Oxford in March, which reported on research in seven countries demonstrating the debilitating effects of the shame associated with poverty and the stigma that can be imposed through the receipt of benefits. The same research was simultaneously drawn upon by $\mathrm{NGOs}^{13}$ and the workers' group at the ILO session, the Worker Vice-Chair introducing the amendment that was ultimately to win through. The Employer ViceChair accepted the sentiment of the workers' group amendment but proposed a rephrasing on the grounds of consistency which, in fact, had the effect of expanding the relevance of the amendment from policy design to include delivery.

Carmona specifically argued for the dignity principle on the basis of its consistency with a human rights-based approach to social protection. Such an approach, she asserted, leads to poverty reduction that is 'more effective and sustainable, as participatory and accountability mechanisms ensure that the voices of social protection beneficiaries are taken into account and programmes are designed to respond to their needs.' Outside the formal meeting there had been much discussion concerning the terms used to describe beneficiaries of the social protection floors. 'Beneficiaries' seemed to some delegates to conjure up the idea of charity and recipients of gifts rather than exercisers of rights. It is because of these concerns that the amendment uses the wordy phrase 'people covered by the social security guarantees'.

\section{Shame and stigma}

The research which informed this process drew on Amartya Sen's ${ }^{14}$ contention that the experience of shame lies at the 'irreducible absolutist core in the idea of poverty', is always present, and arises from the inability to participate fully in society. ${ }^{15}$ Social psychologists suggest that shame is among the most pernicious of the social emotions, creating a sense of powerlessness and lack of agency. ${ }^{16}$ Shame is felt by the individual but is also imposed by society and institutions. Made to feel ashamed, people in poverty can often lose faith in themselves, cut their social ties and lose access to social capital. Social security systems that promote personal dignity stand to overcome the debilitating psychological and social effects of poverty as well as tackling material deprivation. Those that do not, risk eroding individual agency, the ability of people to help themselves.

The research was conducted in different settings and supports Sen's contention. Respondents despised poverty, felt despised by others and frequently despised themselves for being poor. Moreover, they reported that public services very frequently added to their sense of shame and failure. Sometimes this happened because they were required to admit to their poverty and the personal failure that this instilled in order to access the services or support they needed. Sometimes it occurred vicariously simply because of how they felt they were treated. Sometimes, even, their own insecurities may have triggered the response that they feared or merely reinforced their beliefs about the negative light in which other people saw them. Financially dependent on bureaucracies, they believed that they had been turned into numbers under the presumption that they were guilty of being society's failures. This sapped their remaining self-esteem, undermined their confidence and, they felt, lowered their self-efficacy.

The argument made on the basis of this research, and which in turn informed deliberations of Recommendation 202, was that treating recipients with respect and promoting their dignity was not only an appropriate response to the demands of social justice but was likely to have beneficial effects on the effectiveness of 
policy. Simultaneously according recipients respect while meeting their material needs through the provision of social security helps to empower them with the confidence to strive towards self-sufficiency.

\section{Welfare reform}

The British government voted in support of Recommendation 202. Recommendations are not legally binding on governments as ILO Conventions are but, equally, countries cannot opt out of their responsibilities through non-ratification. Recommendation 202 establishes a set of principles against which British social security provision can be assessed. Furthermore, the government is obliged to monitor progress in implementing the protection floor and to 'regularly convene national consultations to assess progress and discus policies for the further horizontal and vertical extension of social security'. ${ }^{17}$ It would be unwise for British governments to presume that Recommendation 202 only has purchase on social security systems that are less developed than in Great Britain. In truth, British social security is arguably demonstrably deficient in a number of respects.

Recommendation 202 includes 17 further principles besides that of dignity, including the universality of protection based on social solidarity, the adequacy and predictability of benefits, efficient and accessible appeals procedures, highquality public services that enhance the delivery of social protection, and achieving the optimum balance between the beneficiaries of social protection and those that fund it.

This is not the place to subject the provisions of the Welfare Reform Act 2012 to comprehensive scrutiny with respect to each of the 18 ILO principles. Focusing then on dignity, there is much in the Act that could potentially enhance the delivery experience, including the reduced number of benefits to be claimed and the promised 'continuous delivery of high-quality, joinedup, effective and consistent services'. However, this needs to be set against the framing of the policy that presumes abuse, intrusive conditionality, the erosion of rights as well as the likely consequences of certain benefit cuts.

The political framing of the rationale for the introduction of universal credit and the associated Work Programme is one of shaming, not dignity:

... after generations in key communities, worklessness has become ingrained into everyday life. The cultural pressure to conform with this lifestyle is enormous, underscored by the easy perception that taking a job is a mug's game. It is this factor which can stop someone's journey back to work in its tracks. (lain Duncan Smith, 2012 ${ }^{18}$ )

The implication is that benefit receipt is a lifestyle choice which, in the degrading words of the ministerial forward to the welfare reform white paper, 'breeds intergenerational poverty'..$^{19}$ In ministerial speeches, benefit recipients are characterised as 'slacking', 'been on benefit for years' and having 'lost the work habit'. They are 'not playing their part', instead they are 'stuck on the dole', 'a burden on the taxpayer' and constitute 'a national crisis'. Deliberately, or not, everyone on benefits, irrespective of the reason, be it the recession, chronic illness or a learning difficulty, is tainted by the same negativity, slacking and being a burden.

This framing is echoed in the structure and the proposed mode of delivery with the emphasis given to conditionality. Conditionality and sanctions have always been present in British social security and are overwhelmingly accepted by claimants. But, while the legislation includes appropriate checks and balances, such subtlety is lost in the summary to the white paper. There, the message is transparent to the point of being threatening: ${ }^{20}$

The clear financial incentive provided by universal credit will be backed up by a strong system of conditionality; unemployed people who can work will be required to take all reasonable steps to find and move into employment... Strengthened conditionality will in turn be supported by a new system of financial sanctions. The new sanctions will provide greater incentives for people to meet their responsibilities.

This presumption that benefit recipients are mostly not fulfilling their responsibilities and require sanctioning in order to do so provides some basis for the imposition of sizeable benefit cuts on the most vulnerable. Certainly there is no justification in terms of fairness or any of the principles of Recommendation 202 including that of 'an optimal balance' between beneficiaries and funders.

The benefit cap, which arbitrarily sets the maximum award of universal credit equal to median earnings after tax and national insurance for working families, is discriminatory, disproportionately affecting those with greatest needs, and breaking the nominal link between benefit levels and need. To the extent that those affected can reduce their expenditure, perhaps by moving into cheaper and probably less suitable
[The Welfare Reform Act] might even be seen as a failure to uphold the principle of social security as a human right 
accommodation (as ministers accept will be the case for those affected by the cuts in housing benefit and its incorporation into universal credit), it is likely to undermine dignity. Shame attached to being unable to house oneself and one's family adequately or to fulfil social obligations and expectations, we know, demonstrably reduces agency, the ability of people to help themselves. Those who are unable to reduce their needs face the added indignity of indebtedness and an arbitrary financial cut in benefit a punishment for the new public offence of being exceptionally needy?

The abolition of council tax benefit, and its replacement with support provided through local authorities subjected to a 10 per cent reduction in budget, provides a further threat to the dignity of benefit recipients. So, too, does returning the functions of the social fund, again, with arguably depleted funding, to local government. Both changes create the potential for discretionary systems rather than the rights-based provision envisaged by Recommendation 202. Both systems will create territorial injustice 'postcode lotteries' as the media is prone to call it - the very reason why local rate rebates and relief were previously brought under national control. Both systems mean that people in poverty will have to beg for assistance, not necessarily to people in the streets but to their representatives in local government, the reincarnation of the Poor Law guardians so hated in history because of their notorious meanness when controlled by the interests of prosperous rate payers. Without adequate funding, local authorities will be forced to make savings from services for those who may be only slightly better off to prevent the re-emergence of absolute poverty in Britain. The 'poorest of the poor' will literally be a burden on the community, going 'cap in hand', shamed in their public confession of failure, and offered public charity only if they can prove themselves to be more deserving than the next poorest person.

\section{Recommendation 202: a key to a healthy welfare system}

In many respects it is too early to know whether the quality of service and the appeals systems proposed by the Welfare Reform Act will prove to be adequate. Likewise, it is difficult to determine at this point whether the implied reduction in benefit entitlement could legitimately be justified with respect to changed national circumstances. It might be concluded that the Act constitutes a failure to maintain the social protection floor and so is at odds with the expectation in Recommendation 202 that provision will be progressively extended to ensure higher levels of social protection for as many people as possible. It might even be seen as a failure to uphold the principle of social security as a human right, but that is a matter for lawyers.

As these reflections on the current bout of British welfare reform indicate, Recommendation 202 is not simply an important instrument to assist emerging economies to construct social security systems that serve the needs of their people and address the scourge of global poverty. It is a lens through which we can better understand the consequences of reform anywhere in the world and a potential defence against reforms that might be counterproductive. The principle of dignity of treatment lies at the heart of a healthy society and a fair and effective social security system.

Robert Walker is Professor of Social Policy and Elaine Chase is Research Officer at the Institute of Social Policy, both at the University of Oxford. Ivar Lødemel is Professor of Social Policy at Oslo and Akershus University College of Applied Sciences.

The authors are most grateful to Richard Exell for sharing his reflections on the process leading to the approval of Recommendation 202, but accept sole responsibility for the conclusions drawn.

1 ILO, Recommendation Concerning National Floors of Social Protection, adopted at the 101st session of the International Labour Conference, 14 June 2012 (Recommendation 202)

2 R Walker, 'Towards the Analysis of Social Policy in a Developing World', in R Surender and R Walker (eds), Social Policy in a Developing World, Edward Elgar, 2013

3 ILO, The ILO Social Security (Minimum Standards) Convention, 1952

4 ILO, Social Security for All: investing in global social and economic development, Issues in Social Protection Discussion Paper 16, 2006

5 See note 4

6 ILO, ILO Declaration on Social Justice for a Fair Globalization, adopted at the 97 th session of the International Labour Conference, 10 June 2008, p10

7 ILO, Report of the Committee for the Recurrent Discussion on Social Protection, 2011

8 ILO, Resolution and Conclusions Concerning the Recurrent Discussion on Social Protection (Social Security), adopted at the 100th session of the International Labour Conference, 2011

9 See note $1, \mathrm{p} 6$

10 See note $1, \mathrm{p} 2$

11 See note 1, p2

12 M Carmona, Promotion of and Respect for Rights and Dignity: a briefing note, letter and enclosure sent to the United Nations Office in Geneva, 12 April, 2012, p1

13 Autonomous Recommendation on the Social Protection Floor, joint statement by a group of NGOs, 2012

14 A Sen, 'Poor, Relatively Speaking', Oxford Economic Papers 35, 1983, p159

15 R Walker, Dignity and Respect: a briefing note, Mimeo, 16 March 2012

16 J P Tangney and K W Fischer (eds), Self-conscious Emotions: the psychology of shame, guilt, embarrassment and pride, Guilford Press, 1995; J Tracy, R Robins and J P Tangney (eds), The Self Conscious Emotions: theory and research, Guilford Press, 2007 17 See note $1, \mathrm{p} 14$

18 I Duncan Smith, Leonard Steinberg Memorial Lecture, Policy Exchange, London, 9 May 2012

19 DWP, Universal Credit: welfare that works, Cm. 795.7, 2011, p1 20 See note $19, \mathrm{p} 4$ 